\title{
Screening of Thyroid Function in the First Half of Pregnancy
}

\author{
SHAILA NAZNINE TANIA ${ }^{1}$, FERDOUSI ISLAM ${ }^{2}$
}

\begin{abstract}
:
Objective: The study was conducted to find out any alterations in thyroid function status in first half of pregnancy (up to 20 weeks), with ultimate aim of deciding the usefulness of routine screening of thyroid function in pregnancy.

Material and methods: A cross-sectional study was conducted in the department of Obstetrics \& Gynaecology, Dhaka Medical College and Hospital, Dhaka, Bangladesh, over a period of one year from July 2011 to June 2012 on pregnant women in their $1^{\text {st }}$ half of pregnancy to screen for the thyroid function. Based on predefined eligibility criteria, a total of 230 pregnant women were purposively included in the study. Thyroid function status was assessed by measuring serum levels of $\mathrm{TSH}$, free thyroxine $\left(F T_{4}\right)$, and free tri-iodothyronine $\left(F T_{3}\right)$. Women with thyroid disorders were excluded.

Results: The mean age of the patients being 24 years. Over $90 \%$ of the women were housewife and majority (88.7\%) was educated. Over one-quarter of women was overweight with mean body mass index being $22.1 \pm 4.4 \mathrm{~kg} / \mathrm{m}^{2}$. The women were predominantly multigravida with $56 \%$ in $1^{\text {st }}$ trimester $44 \%$ in the $1^{\text {st }}$ half of $2^{\text {nd }}$ trimester of pregnancy (13-20 weeks). Based on trimester's specific range of serum TSH in the $1^{\text {st }}$ and $1^{\text {st }}$ half of $2^{\text {nd }}$ trimester (13-20 weeks) of pregnancy, $13 \%$ of the patients were hypothyroid and $3 \%$ were hyperthyroid thus yielding a total of 37(16\%) pregnant women with abnormal thyroid function status.

Conclusion: The study concluded that one in every six women may have thyroid disorder in the first half of pregnancy and subclinical hypothyroidism is four times more common than the subclinical hyperthyroidism.
\end{abstract}

Key words: Screening, Tthyroid function, Pregnancy.

\section{Introduction:}

During pregnancy thyroid disorder is the most commonly encountered endocrine disorder and the prevalence of thyroid dysfunctions among the pregnant women is 2-3\% of all pregnancies and 0.9$2.5 \%$ pregnant women suffering from subclinical hypothyroidism. ${ }^{1,2}$ Thyroid hormones have critical role in development of nervous system and growth of the fetus. $3,4,5$ There is high incidence of thyroid dysfunction during pregnancy resulting in adverse obstetrical outcomes for example, an increased risk of miscarriages, anemia, hypertension, preeclampsia, gestational diabetes mellitus, placental abruption, preterm labour, congestive heart failure, postpartum hemorrhage, birth asphyxia, premature birth, low birth weight, low Apgar score, perinatal death, increased neonatal respiratory distress and decreased childhood cognitive function. $6,7,8,9$ It is, therefore, of utmost significance for the clinicians to identify thyroid dysfunction (subclinical or overt) during early pregnancy, which is apparently euthyroid. ${ }^{10}$ Advances in the assessment of thyroid function also have indicated that interpretation of thyroid function tests depend on the stage of pregnancy. ${ }^{5,9,11}$ The TSH concentrations provide the first clinical indicator for thyroid dysfunction, a 2-fold change in $\mathrm{T}_{4}$ will produce a 100 -fold change in $\mathrm{TSH}^{12}$ So,screening of thyroid function by using serum TSH in pregnancy is the only option to assess the pathophysiologic features of thyroid dysfunctions during pregnancy, which can detect even minor thyroid abnormalities.

1. Junior Consultant (CC in situ), Department of Obstetrics \& Gynaecology, 500 Bedded Mugda General Hospital, Dhaka, Bangladesh.

2. Professor and chair, Department of Obstetrics \& Gynaecology, Dhaka Medical College and Hospital, Dhaka, Bangladesh. 
The objectives of the study were to assess the thyroid status of pregnant women by estimating serum thyroid stimulating hormone (TSH), serum free triiodothyronine $\left(\mathrm{FT}_{3}\right)$ and free thyroxine $\left(\mathrm{FT}_{4}\right)$.Also to find out the association between status of thyroid function with socio-demographic and obstetric characteristics.

\section{Material and methods:}

This cross-sectional study was done in the department of Obstetrics and Gynaecology on 230 pregnant women in collaboration with the departments of Endocrinology, Biochemistry, Pathology and Center for Nuclear Medicine and Ultrasound, Dhaka Medical College and Hospital, Dhaka from July 2011 to June 2012. Pregnant women attending at antenatal clinic in the $1^{\text {st }}$ half of pregnancy were the study population. Where, inclusion criteria were healthy singleton pregnant women up to 20 weeks of gestation. On the other hand the exclusion criteria's were pregnancy with known maternal thyroid disease, suffering from acute febrile illness, chronic disease such as hypertension, diabetes mellitus and renal disease, family history of thyroid disease, patients taking drugs that interfere with thyroid function like lithium, amioderone, steroids, carbamazepine, dopamine and salicylates, women with a history of miscarriage, obese and had other autoimmune disorder. The basis of exclusion criteria was as characterized by American Thyroid Association. ${ }^{5,9,13}$ All the subjects were purposively selected.

Estimation carried out by ADIVA Centaur CP and Radioimmunoassay. Thyroid disorders of pregnant women were diagnosed based on trimester specific serum TSH reference intervals considered from the recommendation of American Thyroid Association Guideline in 2011, where pregnant women with serum TSH ranging from 0.1 to $2.5 \mathrm{mIU} / \mathrm{L}$ in $1^{\text {st }}$ trimester and $0.2-3.0 \mathrm{mIU} / \mathrm{L}$ in the $2^{\text {nd }}$ trimester were taken as normal rage. 5,9 Tietz pregnancy specific reference values for Free Thyroxine $\left(\mathrm{FT}_{4}\right)$ in first trimester 9.0 to $25.7 \mathrm{pmol} / \mathrm{L}$ and in second trimester 6.4 to 20.6 $\mathrm{pmol} / \mathrm{L} .{ }^{14} \mathrm{Although}$, in our laboratory trimester specific reference ranges were not available and only adult values were present as serum TSH (0.35-5.5 mIU/L), serum $\mathrm{FT}_{3}(2.80-9.50 \mathrm{pmol} / \mathrm{L})$ and serum $\mathrm{FT}_{4}$ (9.50$25.50 \mathrm{pmol} / \mathrm{L})$ respectively. The test statistics used to analyze the data were Chi-square $\left(\div^{2}\right)$ test and unpaired Student's t- test with its 95\% confidence interval $(\mathrm{Cl})$. For all analytical tests, the level of significance was set at 0.05 and $p<0.05$ was considered significant. Ethical clearance was obtained from appropriate authority. Privacy and confidentiality were strictly maintained.

\section{Results:}

The mean serum TSH level in first half of pregnancy was $1.63 \pm 0.91 \mathrm{mIU} / \mathrm{L}$ (range $=0.05-4.72 \mathrm{mIU} / \mathrm{L}$ ), while serum $\mathrm{FT}_{3}$ and $\mathrm{FT}_{4}$ levels were $3.4 \pm 0.4$ and $18.6 \pm 3.1 \mathrm{pmol} / \mathrm{L}$ (range: $2.92-4.50$ and $12.9-25.7$ $\mathrm{pmol} / \mathrm{L}$ respectively) (Table I).

\section{Table-I}

Level of thyroid hormones among pregnant women

\begin{tabular}{lcc}
\hline Level of thyroid hormones & Mean $\pm \mathrm{SD}$ & Range \\
\hline $\begin{array}{l}\text { Serum TSH level }(\mathrm{mlU} / \mathrm{L}) \\
(\mathrm{n}=230)\end{array}$ & $1.63 \pm 0.91$ & $0.05-4.72$ \\
$\begin{array}{l}\text { Serum } \mathrm{FT}_{3} \text { level }(\mathrm{pmol} / \mathrm{L}) \\
(\mathrm{n}=37)\end{array}$ & $3.4 \pm 0.4$ & $2.92-4.50$ \\
$\begin{array}{l}\text { Serum } \mathrm{FT}_{4} \text { level }(\mathrm{pmol} / \mathrm{L}) \\
(\mathrm{n}=37)\end{array}$ & $18.6 \pm 3.1$ & $12.9-25.7$ \\
\hline
\end{tabular}

Thyroid function status based on serum level of TSH shows that $13 \%$ of the patients were subclinical hypothyroid, $3 \%$ were subclinical hyperthyroid and the rest (84\%) were euthyroid. Thus, a total of $37(16 \%)$ pregnant women had abnormal thyroid function status (Table II).

\section{Table-II}

Distribution of patients by thyroid function status $(n=230)$

\begin{tabular}{lcc}
\hline Thyroid function status & Frequency & Percentage \\
\hline Subclinical Hypothyroidism & 30 & 13.0 \\
Euthyroidism & 193 & 84.0 \\
Subclinical Hyperthyroidism & 07 & 3.0 \\
\hline
\end{tabular}

Table III shows the demographic characteristics of healthy singleton pregnant women up to 20 weeks of gestation where, over $30 \%$ of the patients were below 20 years, $62.6 \%$ between $20-25$ years and $7 \%$ of the patients were $\geq 25$ years old. The mean age of the patients was $24.1 \pm 4.5$ years. The study subjects were predominantly house-wife (91.3\%). Majority (88.7\%) of women were educated. The mean Body

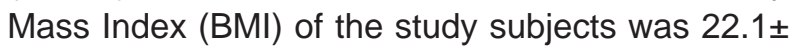
$4.4\left(\mathrm{~kg} / \mathrm{m}^{2}\right)$. 
Table-III

Distribution of patients by demographic characteristics in first half of pregnancy $(n=230)$

\begin{tabular}{lcc}
\hline $\begin{array}{l}\text { Demographic } \\
\text { characteristics }\end{array}$ & Frequency (\%) & Mean \pm SD \\
\hline Age (yrs) & & \\
$<20$ & $70(30.4)$ & \\
$20-25$ & $144(62.6)$ & $24.1 \pm 4.5$ \\
$>25$ & $16(7.0)$ & \\
Occupation & & \\
Service & $20(8.7)$ & - \\
Housewife & $210(91.3)$ & \\
Education & & \\
llliterate & $26(11.3)$ & - \\
Educated & $204(88.7)$ & \\
BMI (kg/m²) * & & \\
$20-24.9($ Normal) & $170(73.9)$ & $22.1 \pm 4.4$ \\
$25-29.9($ Overweight $)$ & $60(26.1)$ & \\
\hline
\end{tabular}

* Ref: Bhattacharya S 2007

Thyroid function status according to obstetric characteristics is shown in Table IV. In the $1^{\text {st }}$ trimester
$11.5 \%$ were subclinical hypothyroid, $84.4 \%$ were euthyroid and $4.1 \%$ were subclinical hyperthyroid and in the $1^{\text {st }}$ half of $2^{\text {nd }}$ trimester (13-20wks) $14.8 \%$ were subclinical hypothyroid, $83.3 \%$ euthyroid and only $1.9 \%$ subclinical hyperthyroid. Multigravida were more frequently subclinical hypothyroid (14.9\%) than the primigravida (9.5\%). No significant difference was observed between thyroid function and obstetric characteristics of the women (in terms of gestational age and gravidity) $(p=0.485$ and $p=0.518$ respectively).

Table $V$ shows the association between age and thyroid function status. Over $45 \%$ of women with abnormal thyroid status were older than 24 years as compared to $31.6 \%$ of euthyroid women $(p=0.091)$ (Table V).

The women with abnormal thyroid status were comparatively older than the women with euthyroid status, although the difference did not reach the level of significance $(p=0.061)$ (Table V).

Table-IV

Thyroid function status according to obstetric characteristics

\begin{tabular}{lcccc}
\hline Obstetric & \multicolumn{4}{c}{ Thyroid function } \\
\cline { 2 - 5 } characteristics & $\begin{array}{c}\text { Hypothyroid } \\
\mathrm{N}(\%)\end{array}$ & $\begin{array}{c}\text { Euthyroid } \\
\mathrm{N}(\%)\end{array}$ & $\begin{array}{c}\text { Hyperthyroid } \\
\mathrm{N}(\%)\end{array}$ & p-value \\
\hline $\begin{array}{l}\text { Gestational age (wks) } \\
1^{\text {st }} \text { trimester }(\mathrm{n}=122)\end{array}$ & $14(11.5)$ & $103(84.4)$ & $5(4.1)$ & 0.485 \\
$1^{\text {st }}$ half of 2 $2^{\text {nd }}$ trimester & $16(14.8)$ & $90(83.3)$ & $2(1.9)$ & \\
$\begin{array}{l}(13-20 \text { weeks) }(\mathrm{n}=108) \\
\text { Gravida }\end{array}$ & & & & \\
$\begin{array}{l}\text { Primi }(\mathrm{n}=74) \\
\text { Multi }(\mathrm{n}=156)\end{array}$ & $7(9.5)$ & $65(87.8)$ & $2(2.7)$ & 0.518 \\
\hline
\end{tabular}

\# Data were analysed using $\mathrm{c}^{2}$ Test

Table-V

Association between age and thyroid function status

\begin{tabular}{lccc}
\hline Age (years) & \multicolumn{2}{c}{ Thyroid function } & p-value \\
\cline { 2 - 4 } Mean aged" 24> 24 & Abnormal $(\mathrm{n}=37)$ & Euthyroid $(\mathrm{n}=193)$ & \\
\hline & $25.3 \pm 4.9$ & Mean \pm SD & \\
& $\mathrm{N}(\%)$ & $23.8 \pm 4.4$ & 0.061 \\
& $20(54.1)$ & $\mathrm{N}(\%)$ & 0.091 \\
& $17(45.9)$ & $132(68.4)$ & \\
\hline
\end{tabular}

If Data were analyzed using Chi-square $\left(\div^{2}\right)$ Test and student's t test 


\section{Discussion:}

Thyroid diseases in pregnancy can affect the health of the mother as well as the child. If has adverse effects on foetal and maternal well being and can extend beyond pregnancy and delivery to affect neuro intellectual development in the early life of child. So it needs to be evaluation. Based on normal range of serum TSH in the $1^{\text {st }}$ and $1^{\text {st }}$ half of $2^{\text {nd }}$ trimesters (1320 weeks) of pregnancy, $13 \%$ of the women were subclinically hypothyroid and $3 \%$ were subclinically hyperthyroid yielding a total of $16 \%$ pregnant women with abnormal thyroid function status. In a study in Poland, $10.4 \%$ of the pregnant women screened for thyroid dysfunction in their $1^{\text {st }}$ trimester exhibited (hypothyroidism), which is quite close to this study findings (13\% hypothyroidism). ${ }^{16}$ In a similar study conducted by Begum in Bangladesh where,clinical and subclinical hypothyroidism together comprised $8 \%$ of the pregnant women and clinical and subclinical hyperthyroidism together formed $7.5 \%$ thus constituting a total $15.5 \%$ with abnormal thyroid function which compares well with the findings of the present study. ${ }^{17}$ According to Klein in contrast to hyperthyroidism, hypothyroidism is quite common in pregnancy, which correlated with this study where subclinical hypothyroidism was $13 \%$ in comparison to subclinical hyperthyroidism(3\%). ${ }^{18}$ However, Spong in a study of screening for subclinical hypothyroidism in pregnant women demonstrated a much lower proportion of hypothyroid status (1 in 40 antenatal mothers screened). ${ }^{19}$

Besides, there was slight but significant ethnic differences in serum TSH concentrations, which should also be taken into account while screening for thyroid hormones in pregnant women. ${ }^{13,20}$ Black and Asian women have TSH values that are on average $0.4 \mathrm{mIU} /$ L lower than in white women; these differences persist during pregnancy. ${ }^{20,21,22}$ Pregnant women of Moroccan, Turkish, or Surinamese descent residing in the Netherlands, have TSH values $0.2-0.3 \mathrm{mIU} / \mathrm{L}$ lower than Dutch women throughout pregnancy. ${ }^{21}$

Kumar and associates found that mean $\mathrm{T}_{4}$ levels began to rise from $16.45 \mathrm{pmol} / \mathrm{L}$ in the first trimester to $16.58 \mathrm{pmol} / \mathrm{L}$ in the second trimester and then decreased in the third trimester to $15.99 \mathrm{pmol} / \mathrm{L}$, they also reported that mean TSH level also rise progressively through the three trimesters of pregnancy from $1.20 \mathrm{mlU} / \mathrm{L}$ in the first trimester to $2.12 \mathrm{mIU} / \mathrm{L}$ in the second trimester and further to $3.30 \mathrm{mIU} / \mathrm{L}$ in the third trimester of pregnancy, which was not consistent with this study findings. ${ }^{22}$ We did not observe the levels of thyroid hormones in each trimester of pregnancy. Some pregnant women attended at first and some at part of 2 nd trimester of pregnancy and their mean levels of $\mathrm{FT}_{3}, \mathrm{FT}_{4}$ and $\mathrm{TSH}$ were $3.4 \pm 0.4$ $\mathrm{pmol} / \mathrm{L}, 18.6 \pm 3.1 \mathrm{pmol} / \mathrm{L}$ and $1.63 \pm 0.91 \mathrm{mlU} / \mathrm{L}$ respectively. Therefore, reference range of TSH values significantly overlaps those of the non pregnant state. So trimesters specific hormone level is mandatory to categorize the patient during pregnancy.

In the study most (63\%) of the patients were in their $2^{\text {nd }}$ decades of life with mean age 24 years (range: 16 - 37 years), there was no association between age and thyroid function alteration. A similar Iranian study conducted on pregnant women of $16-40$ years old, however, demonstrated no significant change in serum TSH level in any of the three trimesters of pregnancy compared to their non-pregnant counterparts. ${ }^{11}$

In this study neither gravidity of women nor their gestational age was found to be associated with their thyroid function status. While an Indian study reported no variations in serum TSH and serum $\mathrm{FT}_{3}$ between trimesters, but there is a significant variation in $\mathrm{FT}_{4}$ between trimesters with values decreasing with advancing gestational age. ${ }^{23}$

From the findings of the study it is evident that thyroid disorder is more or less common in the first half of pregnancy. However, none of the demographic or obstetric characteristics were found to influence thyroid function significantly. Hypothyroidism is more common than the hyperthyroidism.

Limitation of the study was that it was conducted on a small sample size, which lacks generalization of the findings to reference population; the study did not investigate the thyroid function status in the last half of pregnancy and its effect on the fetus or the mother. In-spite of detecting abnormal thyroid function no treatment was given and outcome of babies were not followed up as it is a preliminary report of only screening. As this report shows the presence of abnormal thyroid function a large multicenter controlled study can be conducted to rule out abnormal thyroid function and necessities of treatment to avoid probable adverse effect on mother and foetus.

\section{Conclusion:}

From the findings of the study and discussion thereof it can be concluded that one in every six women may 
have thyroid disorder (primarily hypothyroidism) in the first half of pregnancy. None of the demographic and obstetric characteristics plays any role in the development of abnormality in thyroid function. Subclinical hypothyroidism is far more common than the subclinical hyperthyroidism. The proportion of subclinical thyroid dysfunction (both hypo- \& hyperthyroidism) is no less and frequently remains undiagnosed, unless specific screening program is initiated to disclose thyroid function abnormalities in early gestation. So, if feasible routine screening at least serum TSH level can be done in all pregnant women attending antenatal visit.

\section{References:}

1. Van den Boogaard E, Vissenberg R, Land JA, van Wely M, vad der Post JAM, Goodijin M et al. Significance of (sub)clinical thyroid dysfunction and thyroid autoimmunity before conception and in early pregnancy: a systemic review',Human Reproduction Update 2011;17(5):605-19.

2. Montoro MN.Thyroid and other endocrine disorders during pregnancy. In: Decherney AH, Nathan L, Goodwin TM, Laufer N, editors. Current Diagnosis \& Treatment: Obstetrics \& Gynaecology. 10th Ed. New York: McGraw-Hill; 2007.p. 386-96.

3. Williams GR.Neurodevelopmental and neurophysiological actions of thyroid hormone. Neuroendocrinol J 2008; 20:784-94.

4. Lazarus JH. Thyroid function in pregnancy. Oxf J Br Med Bul 2010; 97(1):137-48.

5. Garber JR, Cobin RH, Garib H, Hennessey JV, Klein I, Mechanick JI et al. Clinical Practice Guidelines for Hypothyroidism in Adults: Cosponsored by the American Association of Clinical. Endoc Prac 2012; 11:1-207.

6. Allan WC, Haddow JE, Palomaki GE, Williams RJ, Mitchell ML, Hermos RJ et al. 2000 'Maternal thyroid deficiency and pregnancy complications: implications for population screening', J Med Screen. vol. 7, pp. 127-30.

7. Karakosta $\mathrm{P}$, Alegakis D, Georgiou V, Roumeliotaki T, Fthenou E, Vassilaki $M$ et al. 2012, 'Thyroid Dysfunction and Autoantibodies in Early Pregnancy Are Associated with Increased Risk of Gestational Diabetes and Adverse Birth Outcomes', JCEM vol. 97, pp. 4464-72.
8. Lazarus JH 2011, 'Screening for Thyroid Dysfunction in Pregnancy: Is It Worthwhile?' J Thyroid Research, pp. 1-4.

9. Stagnaro-Green A, Abalovich M, Alexander E, Azizi F, Mestman J, Negro R et al. Guidelines of the American Thyroid Association for the Diagnosis and Management of Thyroid Disease During Pregnancy and Postpartum. 2011; 21(10): 1081-1125.

10. Abalovich M, Amino N, Barbour LA, Cobin RH, De Groot L, Glinoer D et al. 2007, 'Management of thyroid dysfunction during pregnancy and postpartum: an Endocrine Society clinical practice guideline', J Clin Endocrinol Metab, vol. 92, no. 8 (suppl.), pp. S1-S47.

11. Zarghami N, Rohbani-Noubar M, Khosrowbeygi A 2005, 'Thyroid Hormone Status during Pregnancy in normal Iranian women', Indian Journal of Clinical Biochemistry, vol. 20, no. 2, pp. 182-5.

12. Fatourechi V. Subclinical Hypothyroidism: An Update for Primary Care Physicians. Mayo Clin Proc 2009; 84(1): 65-71. Available at: www.mayoclinicproceedings.com

13. AACE Thyroid Guidelines. The Endocrine society's clinical guidelines. Endocr Pract 2002; 8(6):457-69.

14. Tietz.In: Burtis CA, Ashwood ED, Bruns DE,editors. A Textbook of Chemistry and Molecular Diagnosis. 4th edn. South East Asia: Elsevier: 2006.p.2296-7.

15. Bhattacharya S, Campbell DM , Liston WA, Bhattacharya S, 2007, 'Effect of Body Mass Index on pregnancy outcomes in nulliparous women delivering singleton babies' BMC Public Health, 7:168 doi:10.1186/1471-2458-7-168 available at: http://www.biomedcentral.com/14712458/7/168

16. Matuszek B, Zakoœcielna K, BaszakRadomañska E, Pyzik A, Nowakowski A. Universal screening as a recommendation for thyroid tests in pregnant women. Annals of Agricultural and Environmental Medicine 2011; 18(2): 375-9.

17. Begum SA. Routine Screening of thyroid function in early pregnancy [thesis] (MS): Bangubondhu Sheikh Mujib Medical University, Dhaka. 2004. 
18. Klein RZ, Haddow JE, Faixt JD. Prevalence of thyroid deficiency in pregnant women. Clin Endocrinol 1991; 35: 41-6.

19. Spong CY. Subclinical hypothyroidism: should all pregnant women be screened. Obstet \& Gynaecol 2005; 105:235-6.

20. Price A, Obel O, Cresswell J, Catch I, Rutter S, Barik $\mathrm{S}$ et al. Comparison of thyroid function in pregnant and non-pregnant Asian and western Caucasian women. Clin Chim Acta 2001; 308: 91-8.

21. Benhadi N, Wiersinga WM, Reitsma JB, Vrijkotte TG, van der Wal MF, Bonsel GJ. Ethnic differences in TSH but not in free T4 concentrations or TPO antibodies during pregnancy. Clin Endocrinol (Oxf),2007;66: 765-70

22. Kumar A, Gupta N, Nath T, Sharma JB \& Sharma $\mathrm{S}$. Thyroid function tests in pregnancy. Ind J Med Sci 2003; 57(6): 252-8.

23. Marwaha RK, Chopra S, Gopalakrishnan S, Sharma B, Kanwar RS, Sastry A. Establishment of reference range for thyroid hormones in normal pregnant Indian women. BJOG 2008; 115(5): 602-6. 